\title{
Didactic strategy based on robotics (EDITICA) to promote innovation in higher education
}

\section{Estrategia didáctica basada en la robótica (EDITICA) para propiciar la innovación en la educación superior}

HERNÁNDEZ-HERRERA, Juan Roberto ${ }^{1} *$, CENDEJAS-VALDEZ, José Luis ${ }^{2} \dagger$, FERREIRAMEDINA, Heberto ${ }^{3}$ and VEGA-LEBRÚN, Carlos Arturo ${ }^{4}$

${ }^{1}$ Universidad Latina de América

${ }^{2}$ Universidad de Morelia. Posgrados Tecnologías de la Información

${ }^{3}$ Universidad Nacional Autónoma de México - Campus Morelia. Centro de Investigaciones en Ecosistemas

${ }^{4}$ Universidad Popular Autónoma del Estado de Puebla. Dirección de Calidad del Posgrado y Coordinación de Posgrados CONACYT

ID $1^{\text {st }}$ Author: Juan Roberto, Hernández-Herrera / ORC ID: 0000-0001-9019-6243, CVU CONACYT ID: 699173

ID $1^{\text {st }}$ Coauthor: José Luis, Cendejas-Valdez / ORC ID: 0000-0002-4109-4053, CVU CONACYT ID: 345997

ID $2^{\text {nd }}$ Coauthor: Heberto, Ferreira-Medina / ORC ID: 0000-0003-0150-2355, CVU CONACYT ID: 67744

ID $3^{\text {rd }}$ Coauthor: Carlos Arturo, Vega-Lebrún / ORC ID: 0000-0002-8304-2649, CVU CONACYT ID: 202350

DOI: $10.35429 /$ JSEM.2019.18.6.1.13

Received February 12, 2019; Accepted May 22, 2019

\begin{abstract}
This research proposes a didactic strategy based on robotics to promote innovation in higher education (EDITICA), which is structured in ten stages by information technology professionals can go from simple users or programmers of robots, to develop an inventive ability to create their own prototypes. The nature of the research was based on a quantitative approach to get the statistical analysis of the data generated; exploratory type research was used given the limited material available on the subject in question, also relying on experimental, descriptive, correlational and documentary research. The data generated by the survey was analyzed statistically to observe the correlations of the different variables that confirmed the veracity of the proposed hypothesis. Finally, a quasi-experiment was carried out to put the strategy into practice through two teams that worked motivated and enthusiastic to make their prototype work.
\end{abstract}

Robotics, Technologies, Innovation, Social media

\begin{abstract}
Resumen
La presente investigación propone una estrategia didáctica basada en la robótica para propiciar la innovación en la educación superior (EDITICA), que consta de diez etapas para que profesionales y estudiantes de las tecnologías de la información, pueden pasar de simples usuarios o programadores de robots, a desarrollar una capacidad inventiva para crear sus propios prototipos. La naturaleza de la investigación se fundamentó bajo un enfoque cuantitativo-cualitativo para el análisis estadístico de los datos generados, y dado el poco material existente sobre el tema en cuestión, se utilizó una investigación de tipo exploratoria, apoyándose también en la investigación experimental, descriptiva, correlacional y documental. Los datos generados por la encuesta se analizaron estadísticamente para observar las correlaciones de las diferentes variables que confirmaron la veracidad de la hipótesis propuesta. Finalmente, se llevó a cabo un cuasi-experimento para poner en práctica la estrategia a través de dos equipos que trabajaron motivados y entusiastas hasta hacer funcionar sus prototipos.
\end{abstract}

Robótica, Tecnologías de la información, Innovación, Medios sociales

Citation: HERNÁNDEZ-HERRERA, Juan Roberto, CENDEJAS-VALDEZ, José Luis, FERREIRA-MEDINA, Heberto and VEGA-LEBRÚN, Carlos Arturo. Didactic strategy based on robotics (EDITICA) to promote innovation in higher education. Journal of Technology and Innovation. 2019, 6-18: 1-13

\footnotetext{
* Correspondence to Author (email: jrhernandezh@unla.edu.mx)

$\dagger$ Researcher contributing first author
} 


\section{Introduction}

In institutions of higher level talk about the study of robotics within their academic programs, is to invest in the purchase of kits with robots that include models of educational and experimental type to suppliers such as Lego or Parallax, which in truth are considered attractive and easy to use, but only help the student of computer technology careers in an introductory stage, because they interact with a closed system.

There are no concrete options to bring students to interdisciplinary projects related activities, where they can solve real problems through their own technological developments, as opposed to having to adapt the study programs to the aforementioned commercial kits.

An example of the degree of specialization of robotics in the medical field is proposed by Olanrewaju, Faieza, and Syakirah (2013), where its technological development classifies it according to its application in:

1. Bio-robots for the modeling and simulation of biological systems;

2. Micro-robots that guide surgeries with images;

3. Macro-robots that can be applied in wheelchair manipulators for rehabilitation, among other forms of use.

In the specific case of Mexico, only some Higher Education Institutions (HEIs) develop robotic projects, and of these the majority remain purely educational as a line follower or a robot that emulates a sumo struggle, among others. It is understood then the difficulty for a professional development of robots that meet the automation needs of the different Mexican industries.

According to data from the INTERNATIONAL FEDERATION OF ROBOTICS (International federation of robotics, 2016), sales of industrial robots increased in 2015, especially in Europe and North America. In the old continent there were record figures of 9 percent equivalent to 50,000 units sold. In relation to North America, record increases were also recorded in the US, Canada and Mexico with a total of 34,000 units, which is equivalent to 11 percent more than in 2014.
Even though the previous data suggest Numerous figures in the sale of robots for the Mexican industry, it can be inferred that acquiring purchased or maquilate technology in the country does not have the same weight in technological progress as developing it to have really competitive companies. Having said this, it can be established that the national structural competitiveness is related to that capacity for improvement at a collective level in a country (Álvarez and Marín, 2013).

Currently, as part of the actions to help solve this problem in Mexico, the government has promoted the NATIONAL DEVELOPMENT PLAN (PND) 2013 - 2018, where the strategic lines of action focused on fostering innovation have been defined. the SPECIAL PROGRAM OF SCIENCE, TECHNOLOGY AND INNOVATION (PECITI) between 2014 and 2018.

The main proposals of the PECITI focused on the motivation - stimulation of private investment in research and development (R \& D), thus offering instruments for the development of technological capabilities in organizations, taking into account the priorities of the environment and the creation of projects.

When talking about innovation, Carrillo (2012) defines it as that cumulative learning process, in conjunction with the acquisition of technological, productive and organizational skills that generate an improvement in processes and products in the market. It is understood then, that it is not only the generation of great inventions that suppose a rupture, it can also be a new product or service in the region or the market (Oslo Manual, 2005).

Therefore, it is essential that government entities, companies and the education sector work in an interdisciplinary and integral way through the establishment of collaborative networks that change the paradigm of the traditional way of working to generate robust companies.

These organizations must have entrepreneurial leaders who seek to truly compete with foreign companies through Information and Communication Technologies (Romaní, 2011). 
From the previous problem, the questions arose to find answers to why the situation so lagged with respect to the implementation of robotics in the IHE of Mexico, and thus find a proposal to how the professionals of information technology they can go from simple users or programmers of robots to develop an inventive capacity in the area.

\section{Review of the literature}

\section{i. Competitiveness}

Faced with a globalized economy that imposes new challenges, emphasis must be placed on the innovations that the productive sector could make to excel or even subsist in an increasingly competitive, demanding and changing market. Before starting, it is necessary to understand how to conceive competitiveness in a general way (Porter, Campos, \& Sánchez, 2009).

"Competitiveness is achieved by increasing productivity in the use of resources. The improvement of environmental performance through superior technology and methods will serve to increase productivity and offset the costs of this improvement. Environmental improvement should be conceived not as a regulatory issue, but as an essential part of improving productivity and competitiveness".

Making a basic analysis, the above tells us that productivity is obtained through the efficiency of the company that produces the improvement of environmental performance, through current technology and recent methods.

In Mexico, the value of Small and Medium Enterprises (SMEs) is widely recognized, in a substantial way because of their majority collaboration in the national economy and social contribution, generating $78.5 \%$ of total employment and $52 \%$ of the national GDP (Guillén, 2014).

Competitiveness finds its origin in the ability of the organization to expand competitive advantages, which are born mainly from the value that a SME is able to develop for its buyers and surpass the profit performance (Flores, Gómez, Briones, \& Cervantes, 2013 )).

\section{ii. Scientific and technological research}

However, the relationship between companies and educational institutions is not so common in Mexico, so the study of the networks that form between this conjunction is vital as a reference for its implementation that allows the growth and competitiveness of the Mexican company. In order to appreciate a set of examples that allow us to see the panorama of the aforementioned relationship, there are data from the National Survey of Higher Education Institution Engagement (ENAVI) that can guide in this regard (Ramírez \& Cárdenas, 2013). The various connections represent all the activities of "low complexity" necessary for the development of the projects. All the above exemplifies the totality of links between companies and educational institutions to perform each of the following tasks according to the ENAVI survey ((SEP), 2010):
a) Job vacancies
b) Student internships
c) Professional practices.
d) Academic stays / residences of academics.
e) Social service projects.
f) Technical or administrative training.
g) Promotion of continuing education projects
h) Postgraduate
i) Exchange of personnel.

In the strict plane of connection for scientific and technological research represents a bigger challenge that is shown below in figure 1. Each element (box) is an educational subsystem and circles are companies. The links, on the other hand, are the collaboration for the development of the activities listed below ((SEP), 2010):

a) Transmission of resources for research and management activities in general.

b) Development of joint research.

c) Corporate assistance to academic forums.

d) Academic assistance to business forums.

e) Contribution of companies in jobs with higher education management bodies. 


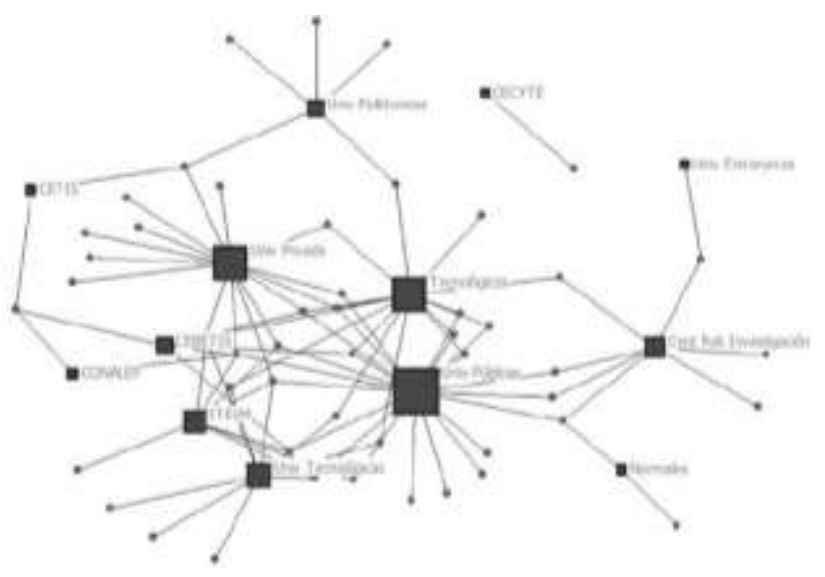

Figure 1 Linkage network for the collaboration of research and development

Source: Ramírez de la Cruz, Edgar \& Cárdenas, Sergio. (2012)

The above activities allow us to understand the degree and types of links that can be achieved to obtain benefits for both sides. There is a long way to go to walk so that this type of work together can be more profitable and stop relying so much on other consumer economies.

Another important problem is to stop the so-called "brain drain", which in other words means that scientific researchers, not finding a possibility of professional and economic progress in their native country, go abroad where scientific and technological research really offers answers to their respectable demands. According to Raúl Delgado Wise, member of the Mexican academy of sciences, of the national system of researchers in his publication Who subsidies to whom? gives as an example the case of Mexico (Delgado, 2013).

"In 2008, Mexico transferred 83 million dollars to its northern neighbor, "in terms of human capital. This research affirms with numbers that the levels of schooling, from the lowest to the highest, with which Mexican migrants arrived in the United States, if they had studied in that country, the cost would be approximately 613 million dollars, according to to the year 2008 .

After the previous analysis, the road to Mexico is not impossible in the field of scientific research, but it goes without saying that the link between companies and the education sector, the brain drain, among other "challenges" are part of of the road that must be traveled in search of stability and national welfare.

\section{iii. Innovation}

According to data analyzed in 2012 by the Nextel Foundation for the promotion and development of technology, in countries such as Korea and Japan, the number of patents per 10,000 inhabitants is $26.56 \%$, in Mexico it is just $0.5 \%$. The above percentages give a sample of the little development that is had in the country for the creation of patents that are reflected in the innovations. In the business world, multinationals have developed due to the diversity of linking, organization and investment strategies in an international context, which translates into constant competitiveness and development as well as the generation of patents. In Mexico, after the arrival of the new millennium, a process of certain stability at the macroeconomic and financial level began, which managed to give confidence to both national and foreign investors, to trade and within what is applicable to all productive activities. This was due to the promotion of reforms in regulatory situations, in addition to the creation of instrumental models for national scientific and technological development.

Specifically, strategic lines of action and priorities focused on fostering innovation were defined through the Special Program of Science and Technology (PECYT) between 2001 and 2006 (VILLAVICENCIO, 2012). The main measures of the PECYT were dedicated to the motivation-stimulus of greater private investment in $\mathrm{R} \& \mathrm{D}$, offering instruments for the development of technological capabilities in business organizations, taking into account the priorities of the environment and creating projects as can be seen in the table one.

\begin{tabular}{|c|c|c|c|c|c|}
\hline & 2007-01 & 2007-02 & 2008-01 & 2009-01 & Total \\
\hline $\begin{array}{l}\text { Creation of own } \\
\text { technology }\end{array}$ & 22 & 40 & 28 & 18 & 111 \\
\hline Copy of technology & 5 & 19 & 8 & 2 & 32 \\
\hline \multicolumn{6}{|l|}{$\begin{array}{l}\text { Acquisition of } \\
\text { technology }\end{array}$} \\
\hline $\begin{array}{l}\text { Already existing for } \\
\text { your application }\end{array}$ & 6 & 16 & 9 & 4 & 35 \\
\hline Through licensing & 2 & 4 & 2 & 1 & 9 \\
\hline $\begin{array}{l}\text { Other type of } \\
\text { transfer }\end{array}$ & 4 & 12 & 7 & 3 & 26 \\
\hline \multicolumn{6}{|l|}{$\begin{array}{l}\text { Acquisition of } \\
\text { technology }\end{array}$} \\
\hline $\begin{array}{ll}\text { For } & \text { your } \\
\text { improvement }\end{array}$ & 2 & 2 & 0 & 1 & 5 \\
\hline Through Licensing & 1 & 2 & 0 & 1 & 4 \\
\hline $\begin{array}{l}\text { Other type of } \\
\text { transfer }\end{array}$ & 1 & 0 & 0 & 0 & 1 \\
\hline Total & 35 & 77 & 45 & 25 & 182 \\
\hline
\end{tabular}

Table 1 Technological details of the approved projects Source: Villavicencio (2012)

HERNÁNDEZ-HERRERA, Juan Roberto, CENDEJAS-VALDEZ, José Luis, FERREIRA-MEDINA, Heberto and VEGA-LEBRÚN, Carlos Arturo. Didactic strategy based on robotics (EDITICA) to promote innovation in higher education. Journal of Technology and Innovation. 2019. 
Likewise, it shows that one fifth of the total of projects is a copy of technology, which at first glance could be seen as negative, but it will depend on the companies involved to learn enough technological capabilities to develop their own technology in the future.

\section{iv. Robotics for competitiveness and educational innovation}

Some examples of efforts made by researchers who have seen project work and the basic application of robotics in the classroom will be reviewed below. Nam and Lee (2011) conducted a study that aimed to develop a program of learning assisted by a programmable instruction robot. The use of the robot allowed significant support to implement the method called skills to solve creative problems.

The results obtained, precisely in the sense of the development and application of creativity as a skill that can be learned at the moment of solving a problem. Particularly, having a good effect on the faculty of divergent thinking in situations out of the ordinary.

According to the research of Hernández (2012), a study was conducted related to students of upper and upper secondary education where the main tool was robotics through a kit developed by a Mexican company.

To analyze the impact of this technology, an experiment was designed that helped to prove that robotics could be an influential factor in the understanding of computational logic, in teamwork and in the development of projects. Significant results were obtained in the learning of young people, because after their arduous stage of study of algorithms and experimentation in that area, they applied their knowledge in the development of a robot designed from a radio control car that could be manipulated with instructions given with the programming language Basic to a Picaxe microcontroller.

Davidsen and Ryberg (2015) in their case study about problem-based learning, used LEGO robots in class to motivate students of computer programming, seeking to reduce their dropout rates which is considered an international problem.
They obtained as a result the scope of several learning objectives, among them, the facilitators had to develop megacognitive strategies and promote them equally among their students, which allowed an important rebound in their final grades and the effective comprehension of the subjects of study.

There are several relevant efforts of the implementation of robotics in the subjects of higher level institutions with careers focused on the study of computer technologies. In short, there is a gap in the research and proposal of an application strategy that satisfies the revised problem that can be solved through robotics.

\section{Methodology}

Given the bases of the problem identification that were raised in the previous section, the scientific process that was developed through the obtaining, processing and analysis of the information, which gave rise to the research model, will be shown below.

\section{i. Nature and approach of the investigation}

The nature of the research is based on a quantitative approach, given that a collection of data will be used that can prove whether the research proposal is true or false, through a numerical measurement and a statistical analysis to establish patterns of behavior to test the proposed strategy (Hernández Sampieri, Fernández Collado, and Baptista Lucio, 2010).

The development of robotics in Mexico is little studied mainly due to the scarce interest of most HEIs to include this type of careers or to implement them in existing ones, since this implies a true professionalization and an interdisciplinary work of information technologies. (IT), electronics and mechanics. Given the previous argumentation, an exploratory-type investigation was carried out, and it also relied on the following types of research:

Descriptive, an important part of the investigation will be dedicated to the description of the situations and contexts that make the robotics in the entity is in a rut that does not allow to grow in this technological branch; 
Correlational, to be able to answer the proposed research questions where the purpose will be to know the degree of relationship between the professionals of the computational technologies, the educational and business institutions, the higher education students as protagonists of the state development of robotics;

And documentary, a concrete and punctual record of all the results obtained in each of the research modules will be carried out using different tools that reliably translate all the important information.

In order to propose a hypothesis to be verified by means of statistical analyzes, the following statements will be taken: true (Hypothesis 1 - H1) and false (Hypothesis 0 $\mathrm{H} 0$ ).

H1: The didactic strategy based on robotics encourages innovation in higher education institutions.

HO: The didactic strategy based on robotics does not favor innovation in higher education institutions.

From which we can deduce a dependent variable that will allow us to consider whether the strategy developed produces innovation in higher education institutions. The independent variable corresponding to the application of robotics that will allow to measure if the prototypes developed in the classroom can, together, make the HEIs innovate.

\section{ii. Methodological model}

The research has a modular process that consists of six phases, as can be seen in Figure 2 , where in each of these all the useful data for the achievement of the objectives are recorded. 1) Research proposal. In the first instance, the context of robotics in HEIs in Mexico should be analyzed in a thorough manner according to the number of public and private institutions of higher education existing. 2) Research design. Detection of the sample for the investigation and of the different tools and methodologies for the registration of the generated information. 3) Synthesis of the data. Analyze through statistics the results of the data collected. 4) Proposed strategy.
Proposal designed to respond to the research problem. 5) Experiment and 6) Final product, to make concrete the transfer of knowledge to technology transfer.

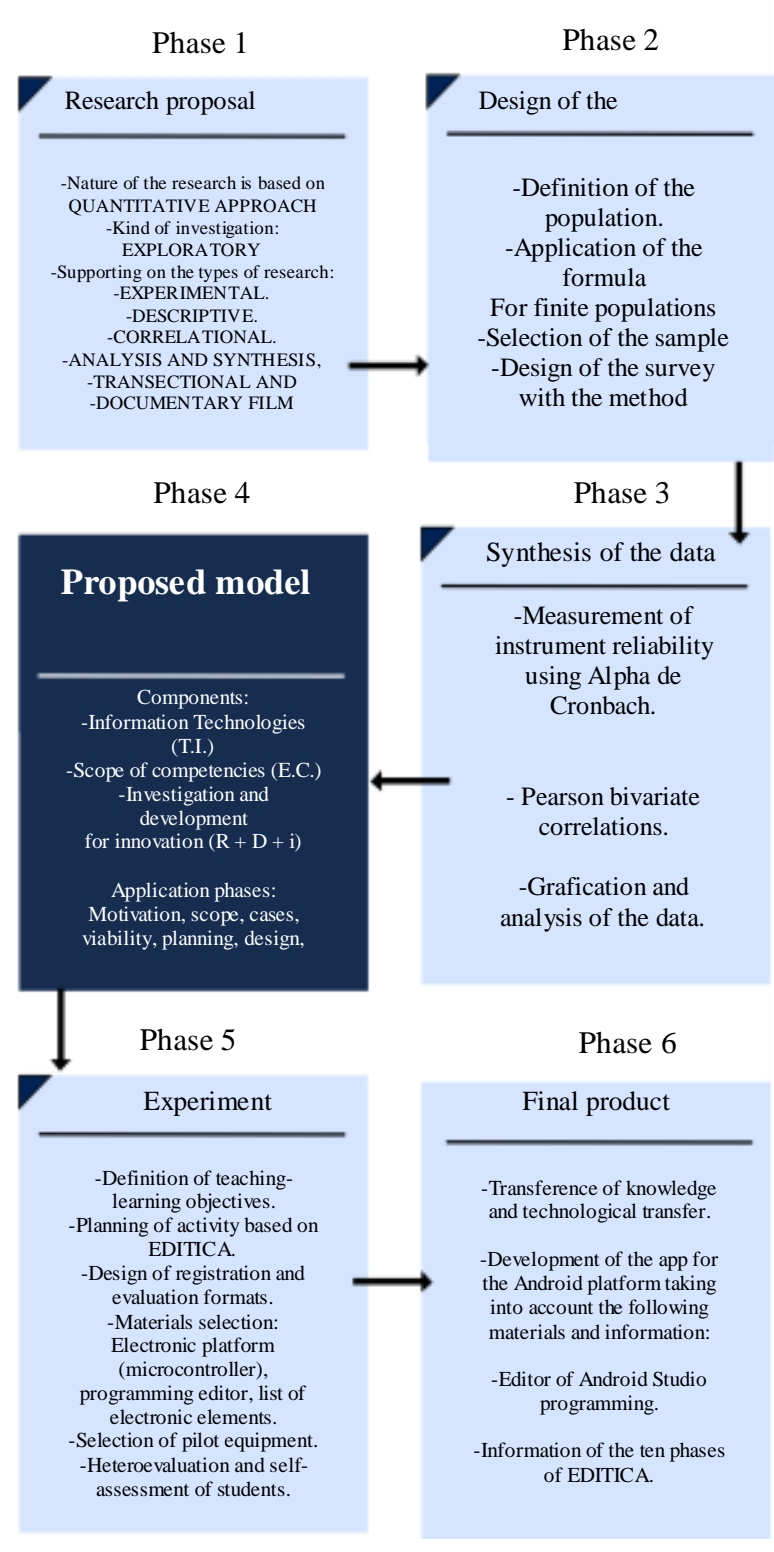

Figure 2 Six phases of the methodological model Source: Own design

The population was formed by the directors or coordinators of academic programs of the public and private universities of the State of Michoacán that offer at least one degree focused on computer technology, and that also has the necessary accreditations endorsed by the SECRETARIAT OF PUBLIC EDUCATION (SEP) of Mexico. The site that contains such information to respond to the need for prior information, is the online system for the RECOGNITION OF OFFICIAL VALIDITY OF FEDERAL AND STATE SUPERIOR STUDIES (RVOE) that is on the home page of the SEP (Undersecretary of education superior, 2014).

HERNÁNDEZ-HERRERA, Juan Roberto, CENDEJAS-VALDEZ, José Luis, FERREIRA-MEDINA, Heberto and VEGA-LEBRÚN, Carlos Arturo. Didactic strategy based on robotics (EDITICA) to promote innovation in higher education. Journal of Technology and Innovation. 2019. 
An online survey was applied to a total of 25 directors or coordinators of technological careers at universities, out of the 27 possible, achieving a level of confidence in the sample of $96 \%$ that was considered acceptable for the purposes of the present investigation. For the calculation of the size of the sample, the socalled "finite populations" were taken, that is, of less than 100,000 inhabitants. This size is considered adequate for the sample of a survey related to a finite population.

\section{iii. Statistical study}

In order to have a reliable metric, the following logical dimensions are proposed corresponding to the independent variable that is of a muntidimensional nature. For the application of robotics the following dimensions and indicators will be taken:

\section{Educational dimension}

Teaching experience. Quantify the degree of experience of the responsible teacher required for the planning and application of the study of robotics.

Managerial experience Quantify the degree of leadership and support for implementation.

Effectiveness of teaching-learning activities. Measure the effectiveness for the design of teaching-learning activities and the corresponding assessment instruments that accompany the process of strategy implementation.

\section{Technological dimensión}

Development of prototypes Establish the degree of teaching experience in the development of robotic prototypes.

Use of robotics kits. Establish the degree of experience of use in commercial robotic products.

\section{Interdisciplinary dimensión}

Self-learning techniques. Measure the degree to which a student can acquire the knowledge, skills and abilities to work with peers and other professionals in an interdisciplinary manner.

Methodology for problem solving. Measure the ability to implement methodologies to solve complex problems for students.
Methodology of implementation of the solution. Measure the strategies that the student has to implement a project in a specific situation.

Measuring instrument. Taking into account the aforementioned dimensions and indicators, the interview was designed for the directors and coordinators to establish the measurement instrument.

The majority of the universities, according to the results of the survey, agree that robotics could generate sustainable projects that benefit part of the population of the state. It may sound paradoxical the previous result, because most of the projects are school prototypes, but it may well be the first step that motivates to start the construction of alternative projects. Sometimes you do not have enough time to learn what you need to start a project, but with a strategy that could give a methodology to learn by bringing that missing motivation to look for other types of applications in robotics.

Table 2 shows the correlations with the highest weighting by research, which were released by the software for the analysis of SPSS data. As you can see the strategy encourages the student's skills can be developed at the time of work both individually and as a team, allowing a step well-founded, as support for the path to innovation (Vota, Gastelú and Muñoz-Repiso, 2011).

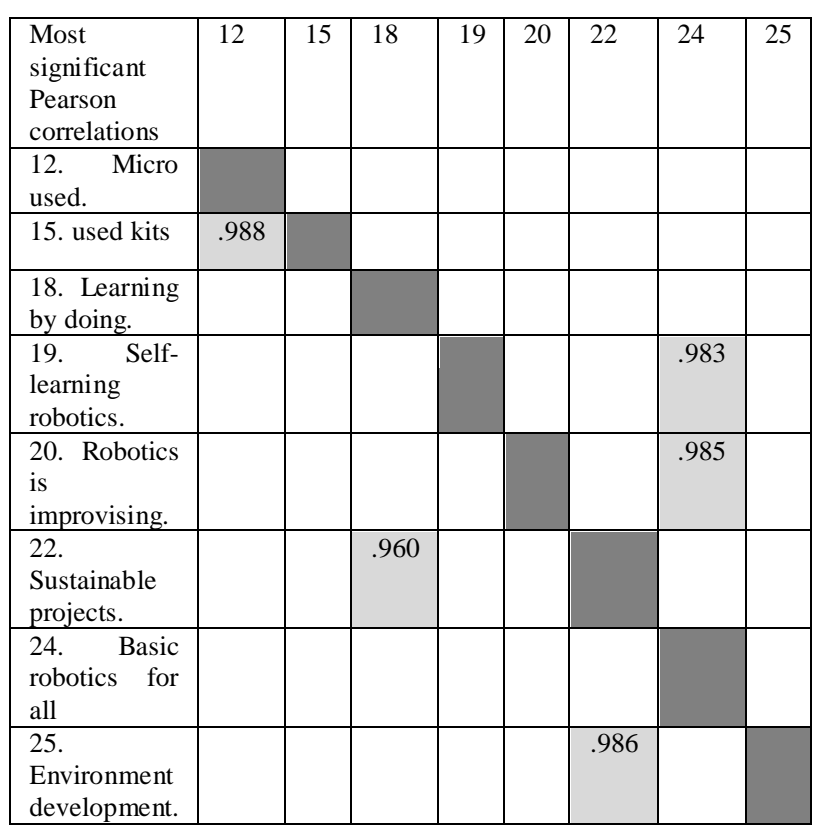

Table 2 Correlations table

Source: Own design 
As a complement to the previous findings of the correlations, it was found that if sustainable projects were developed based on robotics, it could affect the development of the state.

This development would allow a huge step of the environment as mentioned in the publication the White Book of Robotics (Spanish Committee of Automatics, 2010).

\section{Results}

\section{Proposal of levels of use of robotics}

While it is true that robotics is experienced day by day within educational environments. Working with robots requires a multidisciplinary knowledge, ranging from electronics, computer science to mechanics together with the knowledge of sensors, communications, engines and even artificial intelligence. Figure 3 proposes three levels in the use and application of robotics, ranging from minor (Level 3) to the highest level of difficulty (Level 1), which are: Level 3, use of robotic kits programmed through proprietary software that uses graphic programming blocks; Level 2, use of commercial robot kits that the student operates with an external programming language, and finally Level 1 that has a greater degree of complexity, because the student designs and develops the robotic prototype and manipulates it with a External programming language $(\mathrm{C}, \mathrm{C}++$, java, basic, etc.). Levels 2 and 3 are the most used in most HEIs in Mexico, since they involve less effort for their use, but greater economic investment with basic results in the short term and with intermediate training without the need of specialized knowledge.

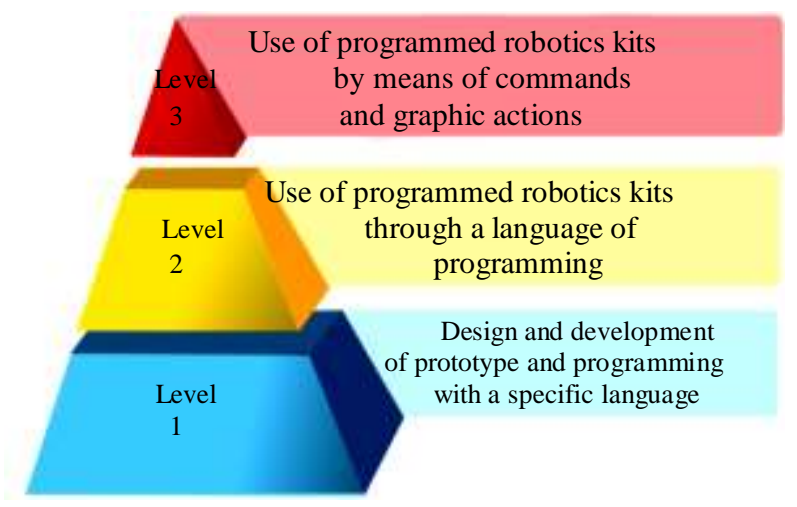

Figure 3 Levels of use of robotics Source: Own design

\section{Proposed strategy}

To implement EDITICA, an inter-disciplinary work is required, where there is a need for a professional in computer technologies and a professional in electronics.

The EDITICA strategy proposes ten phases that are: 1) motivation, 2) scope, 3) cases, 4) feasibility, 5) planning, 6) design, 7) tests, 8) corrections, 9) implementation and 10) evaluation which They described below.

Phase 1. Motivation; Motivation at work can be defined as the set of energetic forces that originate inside the individual and beyond him, which lead to effective work (Dwivedula, 2010). Therefore this element is the beginning of any project and in an educational environment should be emphasized that the teacher and the group of students who develop a prototype, require the generation of a motivational element that allows them to aspire to innovation.

Phase 2. Scope; in this EDITICA stage, the strategy is aligned according to the academic objectives; in a subject, as a complement in a class, in an extra-school project, etc., for the planning and design of the instruments both of introductory practices and of the validation formats for the quantitative and qualitative evaluation of performance. It is proposed that the strategy be applied in the joint work of two subjects, one of electronic court with very specific practices and another that is especially of robotics.

Phase 3. Cases; conduct a review of case studies where robotics has allowed society, and especially the most vulnerable groups of people, to have a better quality of life. An example is the Lokomat robot from Hocoma in Switzerland, which is used in patients who have a spinal cord injury at a different level or grade and has been successfully implemented in many countries around the world (Krewer et al., 2007).

Phase 4. Feasibility; This step requires a time to propose the type of robotic project and the people who will be benefited. The work of the adviser - facilitator is very important, to indicate to the team if a project really can not be carried out due to lack of budget or another difficult problem to overcome. 
The complementary step to the election of the project will be the writing of the objectives that allow to see where to lead the efforts. The documentation starts from this point to describe the prototype in detail.

Phase 5. IT planning; This step answers the question that refers to how information technologies will be used in the construction of the prototype, as shown in figure 4. It must be decided which microcontroller will be used and what will be the way to program it, circuit design and determine the list of additional materials. In order to support the right choice of technologies to be used, four steps are proposed:

How many input and output pins is
required for each electronic or
peripheral component?
What type and how much memory is
necessary for the data?
- What is the language mastered? And the
one that meets the needs of the project
Do you need a microcontroller or an
electronic platform?

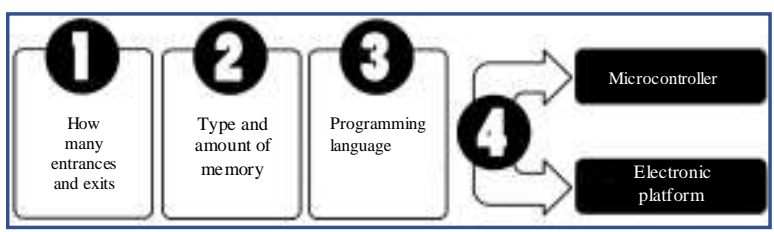

Figure 4 Guide for the planning of information technologies

Source: Own design

Phase 6. Design; In steps 5 and 6 of this list the interdisciplinary work of technology and electronics experts is essential to guide the project team in how the prototype will be designed: communication of the electronic components with the microcontroller and the necessary elements. At the end of this step you must have the prototype armed to start programming in the corresponding language.

Phase 7. Tests; the prototype must be tested in the real application environment, noting all the possible faults found with the armed robotic project and the operating code. An exhaustive observation of the movements or basic functions of the robot must be carried out, according to the objectives of the prototype taking into account the microcontroller and the actuators (Brunete, Hernando, Gambao and Torres, 2012).
Phase 8. Corrections; At this stage it is possible to begin the necessary corrections to work correctly taking into account the needs outlined in step 4. It is possible that while the corrections are made, you can find some kind of variation of the original idea or a good find for another Innovative project. Steps 7 and 8 can be repeated until the operation is as expected.

Phase 9. Implementation; Once the robotics project is working correctly, it will proceed to the implementation and use by the beneficiaries. This step must also be complemented with the final preparation of the documentation and / or a user manual.

Phase 10. Evaluation; It is convenient to make a feedback of the fulfillment of the objectives proposed in phase 2 of the strategy. Steps 7 to 10 have a background based entirely on practice, that is, to test the physical prototype constantly in order to discover the aspects to be improved in order to seek a more robust development (Centro Virtual Cervantes, 2014). In Figure 5 you can see the strategy with each of the aforementioned stages.

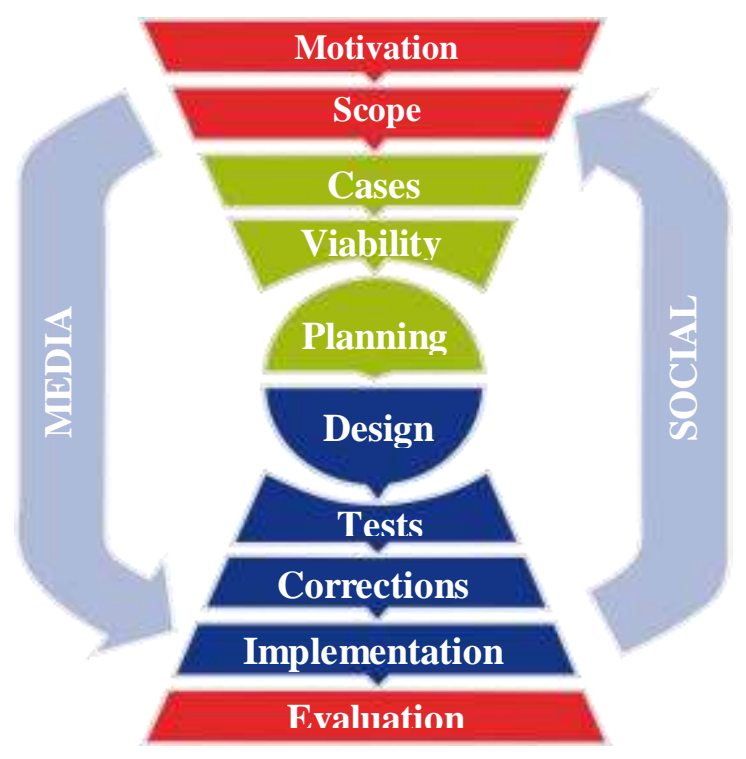

Figure 5 Strategy with its 10 implementation-application phases

Source: Own design.

As a complementary phase, the use of social networks is recommended as a powerful tool for collaborative work, specifically "Social media" could contribute to the development and improvement of the strategy proposed in this research. 
Through social networks you can have access to communication and interaction with people who share the desire to build professional relationships in the field of robotics. EDITICA could benefit from the use of Social Media as described in figure 6.

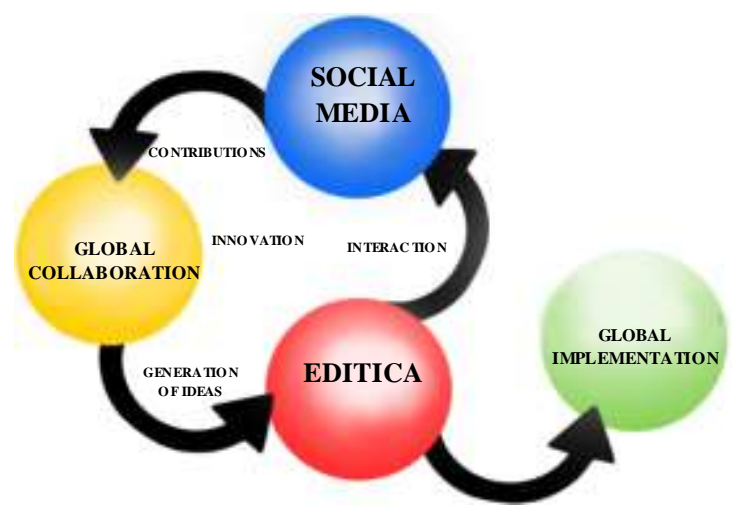

Figure 6 Use of social media in EDITICA Source: Own design

The EDITICA phases encourage the project managers to be facilitators of the search for innovation through the transfer of knowledge, as mentioned by Escuder (2010).

What it means to lay the foundations for a future development of robotics in the country in the long term. For the transfer of the strategy, an application was developed on the use of EDITICA for the android platform with the aim that those interested in EDITICA know about it and that it can give way to technology transfer.

The screen of this app proposes the ten phases of EDITICA which can be explored in a simple way as shown in figure 7 .

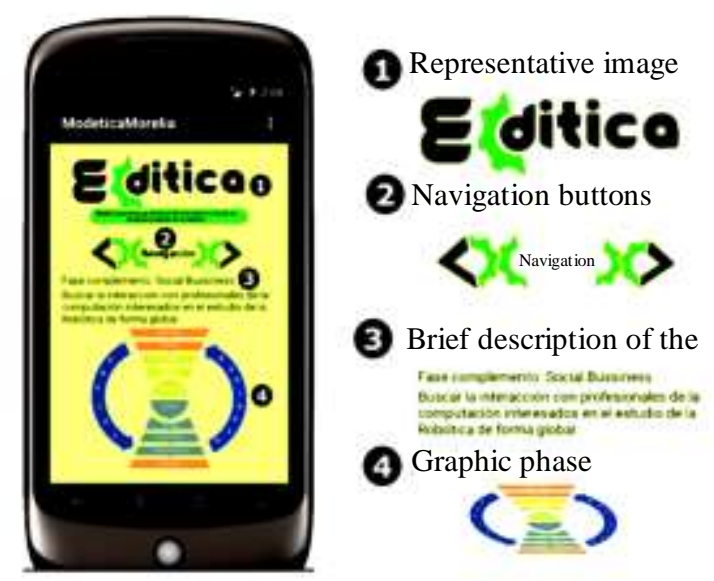

Figure 7 Application for the dissemination of EDITICA Source: Own design

\section{Quasi-experiment}

To implement EDITICA, a quasi-experiment was carried out with the objective of developing a free robotic prototype with limited materials, with the intention of awakening the creativity of the students. At that time only some LEGO kits and some electronic components with arduino cards were available.

Therefore, a team worked with LEGO (Level three of use of robotics) and the DOS team used the arduino platform in conjunction with a limited number of compatible electronic components.

For the UNO team, the purpose of its development was to develop a prototype robot that would have as its main function to provide a technological tool to help people who have a visual disability, by means of a proximity sensor which would alert through a sound, indicating the person to which direction to continue walking to continue a route free of obstacles.

For the elaboration of this project the following requirements must be taken into account:

\section{Software}

- IDE for LEGO MINDSTORMS EV3 Home Edition Version 1.1.1

- Windows 8.1 (64 bits).

- Windows 10 (64 bits).

- $\quad$ Mac OS X 10.6, 10.7 and 10.8 .

* It should be noted that both teams used this software, including the Arduino IDE.

\section{Hardware}

Personal computer with the following characteristics:

- $\quad$ Dual Core Processor at $2.0 \mathrm{GHz}$.
$-\quad 2$ GB of RAM.
space.
2 USB ports available.
An EV3 brick that is provided
with the LEGO EV3 robots.
1 Sensor de proximidad que se
proporciona con los robots LEGO EV3
LEGO parts for robot assembly
2 LEGO EV3 engines

HERNÁNDEZ-HERRERA, Juan Roberto, CENDEJAS-VALDEZ, José Luis, FERREIRA-MEDINA, Heberto and VEGA-LEBRÚN, Carlos Arturo. Didactic strategy based on robotics (EDITICA) to promote innovation in higher education. Journal of Technology and Innovation. 2019. 
- 3 Cables for connection between LEGO EV3 motors to the programmable brick. 1 Mini USB to USB cable to connect the PC with the programmable brick.

2 Wheels for the LEGO robot

- 6 AA batteries

- $\quad 1$ white canvas of $1.50 \mathrm{~m} \times 2.00 \mathrm{~m}$

- Graphic card with support for Microsoft DirectX 9 or higher.

- 2 USB ports.

- $\quad$ XGA screen (1024 x 768).

Being a level 3, with a "simple" programming, the programming code was very small and completely graphic, as can be seen in figure 8 .

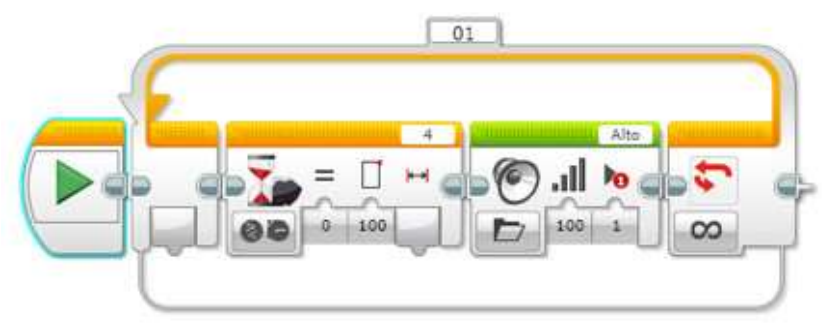

Figure 8 Graphic code for the smart pole Source: Own design

The final prototype was very practical and economical, consisting of the elements mentioned above and a wooden base adjusted to the size of the same (see figure 9).

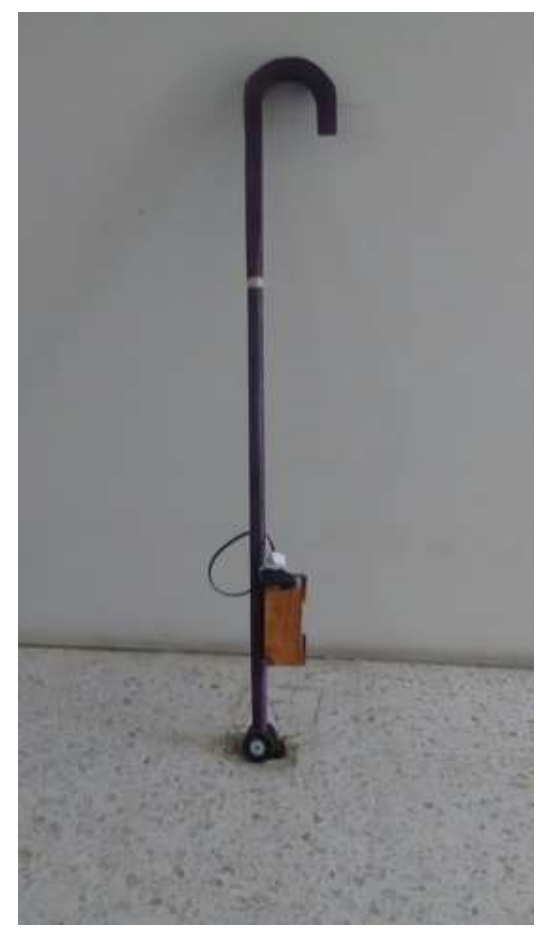

Figure 9 Photograph of cane Source: Own design
The DOS team, designed its own version of the game "Simón dice" to be able to give it different functionalities. They used

$$
\begin{aligned}
& \text { - } \quad \text { Arduino UNO board, } \\
& \text { - } \quad 3 \text { Push buttons. } \\
& \text { - } \quad 3 \text { LED's. } \\
& \text { - } \quad \text { Various cables and resistances. }
\end{aligned}
$$

The electrical diagram of your prototype is presented below in figure 10. The minidevelopment is ready to increase the degree of difficulty adding more LED's and push buttons.

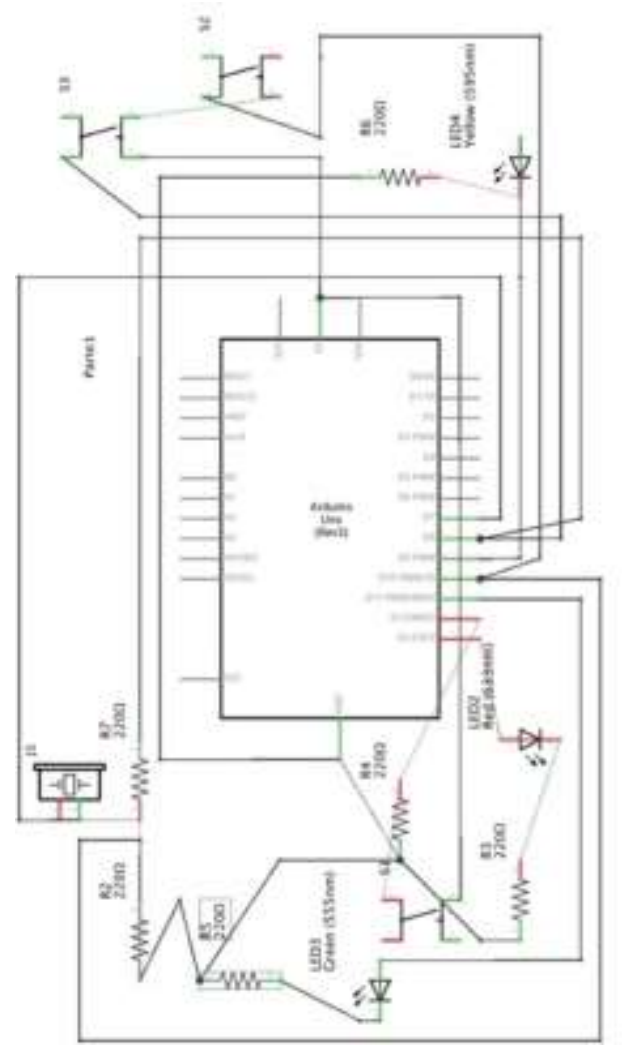

Figure 10 Electric scheme of the game Simon says Source: Own design

At the end of the activity, a selfassessment exercise was performed with the parameters from the highest to the lowest, that is, excellent, very good, good, regular and not enough.

The students themselves were free to evaluate the evaluation criteria related to programming and debugging, assembling the prototype, contributing ideas and even if according to their criteria there was innovation in their participation in the quasi-experiment. A summary of the above can be seen in table 3 . 


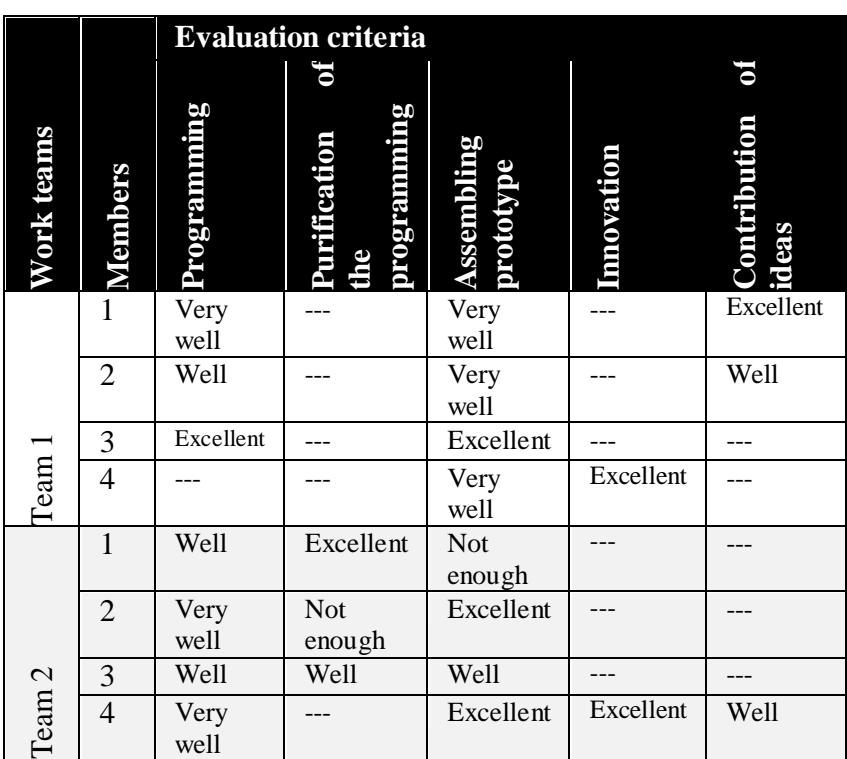

Table 3 Evaluation of the quasi-experiment Source: Own design

\section{Conclusions}

The different statistical analyzes generated, analyzed and interpreted, allow to conclude in a plausible way the following results according to the proposed hypothesis.

The didactic strategy based on robotics promotes innovation in higher education institutions is considered TRUE. This allows to establish that the proposed strategy can be replicated in similar situations of robotics implementation for students of technologicalcomputational careers.

To innovate means to be aware of the opportunities that "are there, but nobody sees them", which can be as complicated as possible but simply nobody had thought of such or such a solution to a problem. Innovating in the field of Robotics involves generating projects that directly affect the development of a specific environment, creating even new products.

Beyond thinking about the expensive robots it is convenient to see the possible generation of mini projects that can go from an economic system for the aid in agriculture to a simple cane that detects by means of a sensor the proximity of an object in the hands of a weak visual. Thinking about the people of the environment and their most urgent needs is also a task for computer professionals.
The IHE need to invest in more programs that allow the development of information technologies focused on robotics, with the purpose of making the leap from being technology users to being direct protagonists of the real change of the environment.

The development of the didactic strategy to promote the development of the environment through the implementation of Robotics (EDITICA) arises from a commitment to innovation having as support the multiple experiences in the field of teaching and the incursion in the area of Robotics Each of the stages was designed with the intention that it could really affect the student's awareness as a true creative potential.

The application of the phases of the strategy in the experiment made it possible to observe in a short time how the student of higher education is motivated to carry out an activity demonstrating attitudes of commitment and concentration for the assembly and operation of the prototype.

Also, in the evaluation part, they were quite committed being honest at the time of the self-evaluation and co-evaluation.

\section{References}

Álvarez, I., \& Marin, R. (2013). FDI and technology as levering factors of competitiveness in developing countries. Journal of International Management,19(3), 232-246.

Brunete, A., Hernando, M., Gambao, E., \& Torres, J. E. (2012). A behaviour-based control architecture for heterogeneous modular, multiconfigurable, chained micro-robots. Robotics and Autonomous Systems, 60(12), 1607-1624.

\section{Carrillo, J. (2012). MULTINACIONALES EN MÉXICO. DILEMAS DE LA INNOVACIÓN EN MÉXICO, 73.}

Comité Español de automática. (2010). Libro Blanco de la robótica: De la investigación al desarrollo tecnológico y futuras aplicaciones. España. Ed. CEA-GTRob. 
Davidsen, J., \& Ryberg, T. (2015). Fourth Issue of the Journal of Problem Based Learning in Higher Education. Journal of Problem Based Learning in Higher Education, 3(2).

Escuder, A. G. P., Vázquez, J. G., \& García, P. P. (2010). Incidencia de las políticas de recursos humanos en la transferencia de conocimiento y su efecto sobre la innovación. Investigaciones Europeas de Dirección y Economía de la Empresa, 16(1), 149-163.

Flores, M. C., Gómez, D. O., Briones, J. B., \& Cervantes, G. P. (2013). Rentabilidad y competitividad en la PYME.

Hernández, J. (2012). La minirrobótica como factor influyente en la obtención de competencias del estudiante de nivel medio superior. Tesis de Licenciatura. Universidad Interamericana para el desarrollo.

International federation of robotics. (2016). IFR press release. Recuperado el 20/11, 2016, disponible en http://www.ifr.org/news/ifr-pressrelease/industrial-robots-post-a-new-salesrecord-in-2015-806/

Krewer, C., Müller, F., Husemann, B., Heller, S., Quintern, J., \& Koenig, E. (2007). The influence of different Lokomat walking conditions on the energy expenditure of hemiparetic patients and healthy subjects. Gait \& posture, 26(3), 372-377.

Manual de Oslo. (2005). Scientific.

Nam, D., \& Lee, T. (2011). The Effect of Robot Programming Education by Pico Cricket on Creative Problem-Solving Skills. In Proceedings of the 19th International Conference on Computers in Education (pp. 1$6)$.

Olanrewaju, O. A., Faieza, A. A., \& Syakirah, K. (2013, June). Current trend of robotics application in medical. In IOP Conference Series: Materials Science and Engineering (Vol. 46, No. 1, p. 012041). IOP Publishing.

Ramírez, E., \& Cárdenas, S. (2013). Un análisis de la vinculación entre empresas mexicanas e instituciones de educación superior a partir de los resultados de la Encuesta Nacional de Vinculación. Perfiles educativos, 35(140), 119131.
Romaní, J. C. C. (2011). El concepto de tecnologías de la información. Benchmarking sobre las definiciones de las TIC en la sociedad del conocimiento. Zer-Revista de Estudios de Comunicación, 14(27).

Secretaría de Educación Pública, C. d. I. y. D. E. C. S. d. E. P. (2015). Encuesta nacional de vinculación en instituciones de educación superior Retrieved from http://www.vinculacion.ses.sep.gob.mx/jsp/gen eral/doctos_estadisticas/ENAVI_21_10_10.pdf

Secretaría de Educación Pública. ENLACE 2014: Estadística de resultados 2008-2014. Retrieved 29/9, $2014 . \quad$ from http://www.enlace.sep.gob.mx/content/ms/docs/ 2014/estadisticas_de_resultados/5.-

ENTIDAD_2008-2014.xls

Subsecretaría de Educación Superior. (2014). Sistema de reconocimiento de validez oficial de estudios. Retrieved 17/05, 2014, from http://www.sirvoes.sep.gob.mx/sirvoes/

Vota, A. M. A., Gastelú, C. A. T., \& MuñozRepiso, A. G. V. (2011). Competencias en Tecnologías de Información y Comunicación (TIC) de los estudiantes universitarios. Revista Latina de comunicación social, (66), 6 . 